\title{
Enhancing Productivity and Profitability of Sesame under Cluster Frontline Demonstration in Morigaon District of Assam, India
}

\author{
Ranjita Bezbaruah $^{1 *}$, Rijusmita Sharma Deka ${ }^{2}$, Juli Sharma ${ }^{3}$ and Pallavi Saikia ${ }^{4}$ \\ ${ }^{1}$ Horticultural Research Station, Assam Agricultural University, \\ Kahikuchi, Guwahati, Assam, India \\ ${ }^{2}$ Krishi Vigyan Kendra, AAU, Morigaon, Assam, India \\ ${ }^{3}$ Krishi Vigyan Kendra, AAU, Nagaon, Assam, India \\ ${ }^{4}$ Krishi Vigyan Kendra, AAU, Golaghat, Assam, India \\ *Corresponding author
}

\section{A B S T R A C T}

Keywords

Sesame, Production, Cluster Frontline Demonstration, Net return, B: C Ratio

\section{Article Info}

Accepted:

12 October 2020

Available Online:

10 November 2020
Adoption of improved production technologies of sesame offers a great scope for increasing productivity and profitability to overcome the problem of low productivity under rainfed cultivation under poor management and input starved conditions. The study was conducted by Krishi Vigyan Kendra, Morigaon during summer 2016 and 2017 under Cluster Frontline Demonstration of Oilseed (CFLD) programme to enhance the productivity and profitability of sesame by transfer of improved technology. The result revealed that the maximum seed yield of sesame was obtained under demonstrated plots ranged between $627 \mathrm{~kg} / \mathrm{ha}$ to $672 \mathrm{~kg} / \mathrm{ha}$ with an average of $645 \mathrm{q} / \mathrm{ha}$ which was 25.97 percent higher as compared to local check with an average of $5.12 \mathrm{q} / \mathrm{ha}$. Extension gap between demonstrated plots and local check was found with an average of $1.33 \mathrm{q} / \mathrm{ha}$. The maximum average net returns (Rs. $39050 \mathrm{ha}^{-1}$ ) and benefit cost ratio (2.23) were recorded under demonstrated plots as compared to local check (Rs. $15700 \mathrm{ha}^{-1}$ and 1.22, respectively).

\section{Introduction}

Sesame (Sesamum indicum L.) is the oldest indigenous oilseed crop, with longest history of cultivation in India. It is called as 'queen of oilseeds crops' by virtue of its excellent oil quality. It is having the highest oil content (46- 64\%) and dietary energy $(6355 \mathrm{kcal} / \mathrm{kg})$ its oil unlike other fats is highly stable and does not develop rancidity leading to loss of flavor and vitamin (Sing et al., 2018). Sesame or gingelly is commonly known as til in Assamese. India ranks first in world with 19.47 Lakh ha area and 8.66 Lakh tonnes production. The average yield of sesame (413 $\mathrm{kg} / \mathrm{ha}$ ) in India is low as compared with other countries in the world $(535 \mathrm{~kg} / \mathrm{ha})$. The main reasons for low productivity of sesame are its rainfed cultivation in marginal and sub marginal lands under poor management and input starved conditions. However, improved varieties and agro production technologies 
capable of increasing the productivity levels of sesame are now developed for different agro ecological situations in the country. A well managed crop of sesame can yield 1200 $1500 \mathrm{~kg} / \mathrm{ha}$ under irrigated and 800 - 1000 $\mathrm{kg} / \mathrm{ha}$ under rainfed conditions. As the production of sesame is comparatively low in the Morigaon district and farmers are interested to cultivate sesame during summer season as due to flood they were not able to go for Sali rice production. Use of improved production technologies of sesame offers a great scope for increasing productivity and profitability. Keeping in this view demonstrations on sesame were conducted to know improve the productivity and profitability of sesame in Morigaon district of Assam.

\section{Materials and Methods}

The cluster front line demonstrations were conducted on 88 demonstrations at farmer's field of seven villages viz. Parojari, Silsaku, Morakolong, Sarantara, Oujari, Katalamaraand, Baghorain 3 clusters covering 35 hectares in District of Morigaon during Summer 2016 and 2017in rain fed condition on low to medium soil fertility status. The package of practice of improved production technologies such as improved variety, seed treatment, plant protection measures were adopted in demonstrated plots. The HYV of Kaliabor local has been used. Seed treatment is completed with PSB @ $50 \mathrm{~g} / \mathrm{kg}$ of seed \& Azotobacter $50 \mathrm{~g} / \mathrm{kg}$ of seed. Line sowing method is used for seed sowing in demonstrated plots. Row to row distance 45 $\mathrm{cm}$ and plant to plant distance $10 \mathrm{~cm}$ is kept under demonstration practices. Seed rate of 4 $\mathrm{kg} / \mathrm{ha}$ was kept under demonstrated plots. Organic manure viz., vermicompost @ 2.18 $\mathrm{q} /$ ha have been applied. Weed management in demonstrated plots were done by hand weeding at 25 DAS. During infestation by insect pest neem based pesticides have been used. The crop was sowed during 25.03.2016 and 20.03.2017 and harvested 08.09.2016 onward to 12.09.2017 onward when the capsules are greenish yellow and leaves turns yellow colored. The technology index shows the feasibility of the evolved technology at the farmers' field. The lower the value of technology index more is the feasibility of the technology. The data were analyzed with appropriate statistical procedures. To estimate the technology gap, extension gap and the technology index the formulae given by Samui, et al., (2000) as mentioned below have been used.

Technology gap = Potential yield Demonstration yield

Extension gap $=$ Demonstration yield Farmers yield

Technology index $=\{($ Potential yield Demonstration yield) / Potential yield $\}$

\section{Results and Discussion}

\section{Yield characters}

The data on yield attributing characters of sesame are presented in Table 1 showed that the maximum seed yield of sesame was found under demonstrated plots ranged between $510 \mathrm{~kg}$ ha $^{1}$ to $780 \mathrm{~kg}$ ha ${ }^{1}$ in 2016 and 2017 with an average of $645 \mathrm{~kg}$ ha ${ }^{1}$ as compared to local check with an average of $324 \mathrm{~kg}$ ha ${ }^{1}$. This may be due to the adoption of improved practices of high yielding variety, line sowing, seed treatment etc. Similar enhancement in seed yield of Sesame under demonstrated plots is reported by Sagar et al., (2004), Deshmukh et al., (2014) and Patel et al., (2014). Yield of the front line demonstration trials and potential yield of the crop was compared to estimate the yield gaps which were further categorized into technology gap and extension gaps Hire math and Nagaraju, (2009). 
Table.1 Grain yield performance of cluster frontline demonstration on Sesame

\begin{tabular}{|c|c|c|c|c|c|c|c|c|c|c|}
\hline \multirow[t]{2}{*}{ Year } & \multirow[t]{2}{*}{ Area } & \multirow{2}{*}{$\begin{array}{l}\text { No of } \\
\text { FLDs }\end{array}$} & \multirow[t]{2}{*}{ Variety } & \multicolumn{3}{|c|}{ Yield(kg/ha) } & \multirow[b]{2}{*}{$\begin{array}{c}\text { Percent } \\
\text { increase } \\
\text { over } \\
\text { farmers } \\
\text { practices }\end{array}$} & \multirow{2}{*}{$\begin{array}{c}\text { Techn } \\
\text { ology } \\
\text { gap } \\
\text { (kg/ha) }\end{array}$} & \multirow{2}{*}{$\begin{array}{c}\text { Extensio } \\
\text { n gap } \\
\text { (kg/ha) }\end{array}$} & \multirow{2}{*}{$\begin{array}{c}\text { Techno } \\
\text { logy } \\
\text { index } \\
(\%)\end{array}$} \\
\hline & & & & $\begin{array}{c}\text { Potential } \\
\text { (kg/ha) }\end{array}$ & $\begin{array}{c}\text { Recomm } \\
\text { ended } \\
\text { practices } \\
\text { (kg/ha) }\end{array}$ & $\begin{array}{c}\text { Farmers } \\
\text { practices } \\
\text { (kg/ha) }\end{array}$ & & & & \\
\hline 2016 & 15 & 38 & $\begin{array}{l}\text { Kaliabor } \\
\text { Local }\end{array}$ & 900 & 510 & 263 & 93.91 & 390 & 247 & 43.33 \\
\hline 2017 & 20 & 50 & $\begin{array}{l}\text { Kaliabor } \\
\text { Local }\end{array}$ & 900 & 780 & 385 & 103.0 & 120 & 395 & 13.33 \\
\hline Average & & & & & 645 & 324 & 98.46 & 255 & 321 & 28.33 \\
\hline
\end{tabular}

Table.2 Economics of front line demonstration of Sesame

\begin{tabular}{|c|c|c|c|c|c|c|c|c|c|c|}
\hline \multirow[t]{2}{*}{ Year } & \multicolumn{2}{|c|}{$\begin{array}{c}\text { Cost of cultivation } \\
\text { (Rs./ha) }\end{array}$} & \multicolumn{2}{|c|}{$\begin{array}{l}\text { Gross Return } \\
\text { (Rs./ha) }\end{array}$} & \multicolumn{2}{|c|}{$\begin{array}{l}\text { Net Return } \\
\text { (Rs./ha) }\end{array}$} & \multirow{2}{*}{$\begin{array}{l}\text { Additional } \\
\text { Return } \\
\text { (Rs./ha) }\end{array}$} & \multirow{2}{*}{$\begin{array}{c}\text { Net } \\
\text { return } \\
\text { increase } \\
\text { over } \\
\text { FP }(\%)\end{array}$} & \multicolumn{2}{|c|}{ B:C ratio } \\
\hline & RP & FP & $\mathbf{R P}$ & FP & RP & FP & & & $\mathbf{R P}$ & FP \\
\hline 2016 & 17300 & 12200 & 51000 & 26300 & 33700 & 14100 & 19600 & 1.40 & 1.95 & 1.16 \\
\hline 2017 & 18000 & 13500 & 62400 & 30800 & 44400 & 17300 & 27100 & 1.57 & 2.5 & 1.28 \\
\hline Average & 17650 & 12850 & 56700 & 28550 & 39050 & 15700 & 23350 & 1.49 & 2.23 & 1.22 \\
\hline
\end{tabular}

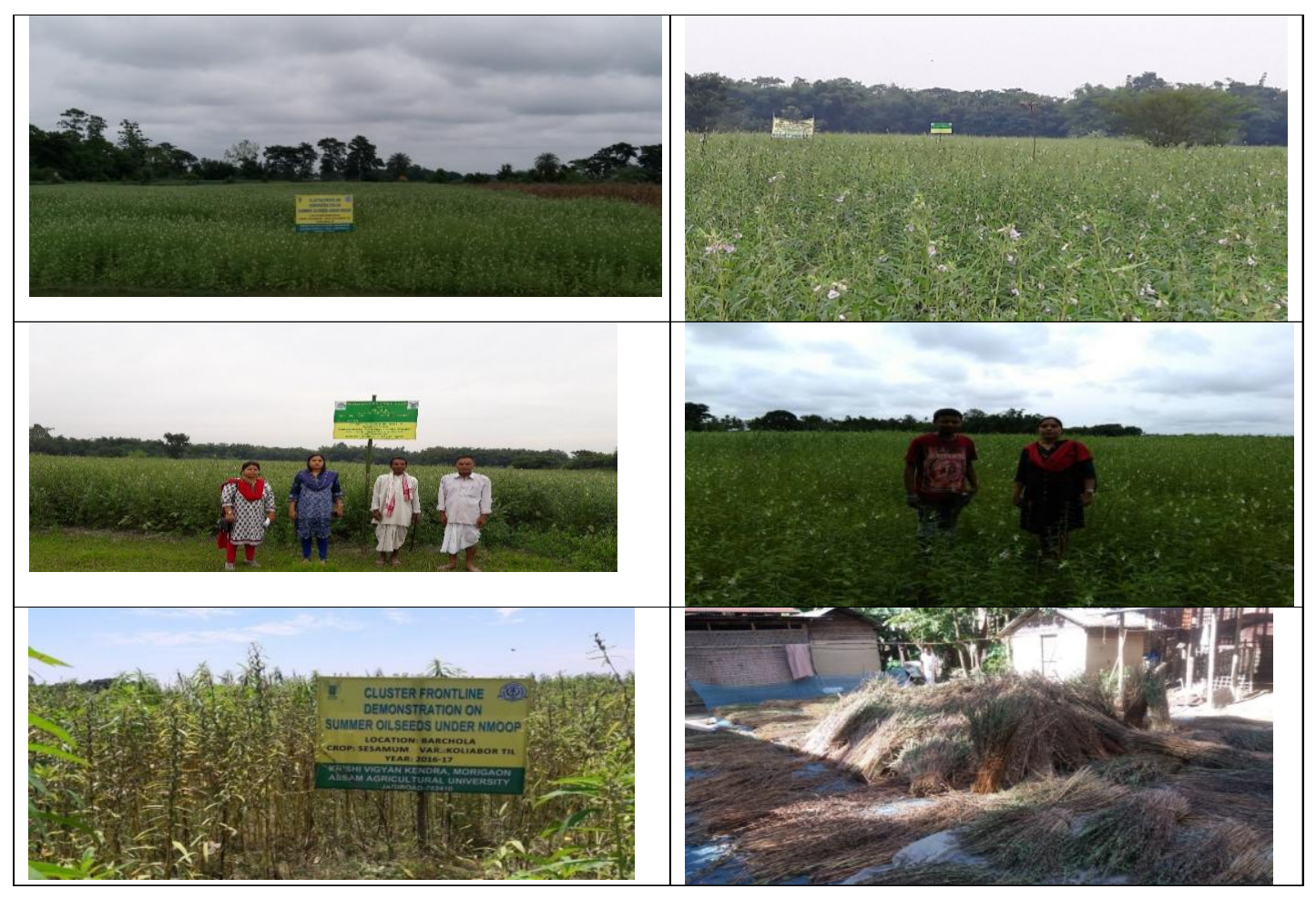


The technology index indicated the feasibility of evolved at the farmer field. Lower the value of technology index more is the feasibility of the technology demonstrated.

\section{Extension gap and technology gap}

The data on Extension gap \& Technology gap of sesame are presented in (Table 1) revealed that the extension gap between demonstrated plots and farmer's plots was recorded with an average of $321 \mathrm{~kg} \mathrm{ha}{ }^{1}$. Technology gap of variety was found with an average of 255 $\mathrm{kg} / \mathrm{ha}$ due to lack of rainfall during flowering and pod formation stage. The results clearly showed that due to knowledge and adoption of scientific practices by the farmers, the yield of Sesame could be increased by 98.46 percent over the yield obtained under farmers' practices. The above findings are similar with the findings of Dubey et al., (2010) and Yadav et al., (2004)

\section{Economic return}

The data on Economic return of sesame are presented in (Table 2) illustrated that the maximum gross return of crop was obtained under demonstrated plots ranged from 51000 Rs $\mathrm{ha}^{1}$ to $62400 \mathrm{Rs} \mathrm{ha}^{1}$ with an average of $56700 \mathrm{Rs}$ ha ${ }^{1}$ as compared to local check with an average of $28500 \mathrm{Rs} \mathrm{ha}^{1}$ in 2016 and 2017. Maximum Net return was obtained under demonstrated plots ranged from $33700 \mathrm{Rs} \mathrm{ha}^{1}$ to $44400 \mathrm{Rs}^{1}{ }^{1}$ with an average of $39050 \mathrm{Rs}$ ha ${ }^{1}$ as compared to local plots with an average of 15700 Rs ha ${ }^{1}$. Maximum B:C Ratio was obtained under demonstrated plots ranged from 1.95 to 2.5 with an average of 2.23 as compared to local check with an average of 1.22. Total cost of cultivation under demonstrated plots was found $17650 \mathrm{Rs}$ ha ${ }^{1}$ as compared to local check with an average of $12850 \mathrm{Rs} \mathrm{ha}^{1}$. The result is confirmed with similar findings of front line demonstrations on oilseed crops by Yadav et al., (2004),
Singh et al., (2012) and Lathwal (2010). The additional average net return of $23350 \mathrm{Rs} \mathrm{ha}^{1}$ and $1.49 \%$ percent increase of net return over farmer's practice were observed.

The research study clearly showed that the front line demonstration was effective in changing attitude of farmers against cultivation of sesame production technology. The results reflected that the maximum seed yield of sesame was under demonstrated plots. The farmer's acceptance of the new technologies also well observed. Thus, Front Line Demonstration was helpful in replacement of local varieties with improved varieties of Sesame crops along with other improved practices.

\section{References}

Deshmukh, G., Patel, H.B. and Patel M.R. (2014). Frontline Demonstration Influences on Knowledge and Adoption of Mustard Growers. Gujarat Journal of Extension Education, 25(1): 27-30.

Dubey, S., Tripathi, S., Singh, P. and Sharma R.K. (2010). Yield gap analysis of black gram production through frontline demonstration. Journal of Progressive Agriculture, 1(1): 42-44.

Hire math, S.M. and Nagaraju, M.V. (2009). Evaluation of Frontline demonstration trials on onion in Haveri district of Karnataka. Karnataka Journal of Agricultural Sciences, 22(5): 10921093.

Lathwal, O.P. (2010). Evaluation of front line demonstrations on blackgram in irrigated agro ecosystem. Annual Agriculture Research, 31(1\&2): 24-27.

Patel, R.N. and Patel, J.R. (2014). Impact of Front Line Demonstration on Mustard Grower. Gujarat Journal of Extension Education, 25(1): 91-92.

Sagar, R.L. and Chandra, G. (2004). Frontline demonstrations on sesame in west 
Bengal. Agriculture Extension Review, 16(2): 7-10.

Samui, S.K., Maitra, S., Roy, O.K., Mondal, A.K., Saha D. (2000). Evaluation on frontline demonstration on groundnut. Journal of the Indian Society of Coastal Agriculture Research, 18(2): 180-183.

Singh, Jagmohan., Dhillon, B..S., Sing, A.P. (2012). Frontline demonstration an effective tool for increasing the productivity of summer moong in Amritsar district of Punjab Asian Journal of Soil Science, 7(2): 315-318.
Singh, K.H., Meena, K.C., Meena, B.L. and Meena, R. (2018). Effect of front line demonstration on sesame in eastern region of Rajasthan. International Journal of Microbiology Research, 10(3):1024-1026

Yadav, D.B., Kamboj, B.K. and Garg, R.B. (2004) Increasing the productivity and profitability of sunflower through Crop demonstrations in irrigated agro ecosystem of eastern Haryana. Haryana journal of Agronomy, 20 (1\&2): 33-35.

\section{How to cite this article:}

Ranjita Bezbaruah, Rijusmita Sharma Deka, Juli Sharma and Pallavi Saikia. 2020. Enhancing Productivity and Profitability of Sesame under Cluster Frontline Demonstration in Morigaon District of Assam, India. Int.J.Curr.Microbiol.App.Sci. 9(11): 1678-1682. doi: https://doi.org/10.20546/ijcmas.2020.911.200 